I N S T I T U T O

$\mathrm{DE}$

M E D I C I N A

T R O P I C A L

$\mathrm{DE}$

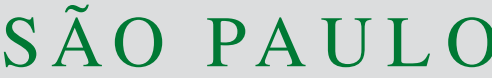

JOURNAL OF THE SÃO PAULO INSTITUTE OF TROPICAL MEDICINE

${ }^{1}$ Faculdade Israelita de Ciências da Saúde Albert Einstein, São Paulo, São Paulo, Brazil

${ }^{2}$ Hospital Israelita Albert Einstein, Departamento de Hemoterapia e Terapia Celular, São Paulo, São Paulo, Brazil

${ }^{3}$ Universidade de São Paulo, Faculdade de Medicina, Departamento de Moléstias Infecciosas e Parasitárias, São Paulo, São Paulo, Brazil

*These authors contributed equally to the article

Correspondence to: Vivian lida AvelinoSilva

Universidade de São Paulo, Faculdade de Medicina, Departamento de Moléstias Infecciosas e Parasitárias, Av. Dr. Enéas de Carvalho Aguiar, 470, CEP 05403-000, São Paulo, SP, Brazil

Tel: +55 1130618347

E-mail: viviansilva87@gmail.com

Received: 16 April 2021

Accepted: 24 June 2021

\section{Demographics and serological profile of blood donors who opt for the confidential unit exclusion in a blood bank in Sao Paulo, Brazil}

\author{
Marcella Vizcaya Val Delatorre ${ }^{{ }^{*}}$, Kalyne M. Batalha ${ }^{{ }^{*}}$, Leandro Dinalli \\ Santos ${ }^{(1)}$, Carolina Bonet-Bub ${ }^{\left({ }^{2}\right.}$, Vivian lida Avelino-Silva ${ }^{(1,3}$
}

\section{ABSTRACT}

Blood transfusion is still an irreplaceable therapeutic modality, widely applied to medical care. Clinical interviews and laboratory testing for transfusion-transmitted infections (TTI) are routinely performed to prevent TTI among the recipients. However, there is still a residual risk of TTI, and some blood banks have adopted the confidential unit exclusion (CUE) as an additional safety strategy. In this study, we investigated the demographic characteristics and laboratory results of the screening of TTI among blood donors who opted for the CUE, compared to blood donors who did not opt for the CUE. In this study, we included 32,261 blood donations collected in a single blood bank in Sao Paulo, Brazil. A very small proportion of donors $(0.25 \%)$ opted for the CUE. They were mainly single males and were more likely to have HBV, syphilis, and other positive results in the combined screening for TTI, in comparison with those who did not opt for the CUE. This difference was statistically significant in both the univariable and the multivariable analysis adjusted for age, gender, marital status and years of schooling. Our findings highlight that CUE may be a useful tool to improve the safety for blood recipients, but its efficiency is context-dependent.

KEYWORDS: Blood donors. Transfusion. Screening. Confidential unit exclusion. Transfusion-transmitted infections.

\section{INTRODUCTION}

Blood transfusion is still an irreplaceable therapeutic modality, widely applied to medical care. In the United States (USA) alone, 13.6 million units of whole blood and red blood cells are collected and nearly 21 million blood components are transfused yearly ${ }^{1}$. In Europe, 18,374,971 units of red blood cells were donated, and $20,674,603$ transfusions occurred in $2017^{2}$. In Brazil, a yearly average of 3,608,436 blood donations was registered between 2014 and 2016, and in 2016 alone 2,840,988 transfusions were performed in the country ${ }^{3}$.

Preventing transfusion-transmitted infections (TTI) among recipients is a central issue in the blood transfusion setting. The screening of blood donors includes a standardized interview addressing clinical and behavioral aspects; laboratory testing for hepatitis B, hepatitis C, HIV, syphilis, HTLV-1/2; and addicional screening tests for TTI such as Chagas disease and malaria in endemic areas ${ }^{4-6}$. The laboratory techniques used in blood donor screening include serological and molecular tests ${ }^{7}$.

Despite the meticulous screening process, there is still a residual risk of TTI. During the interview, blood donor candidates may omit information on exposures or symptoms related to TTI because they believe that their blood is safe, or because 
they feel some of the questions are too intimidating ${ }^{8}$. In addition, some donors may have limited understanding of the questions asked during the interview, particularly those concerning sexuality and sexual behaviors. For example, some donors may neglect the concept of sexually transmitted infection (STI) and may deny any previous episode even though they have already had an STI; some donors may also not consider oral and anal sex within the concept of sex, even when the definitions are stated by the interviewer ${ }^{9}$. Some donors may deliberately omit risk exposures because they want their blood to be tested for HIV and other STI without having to undergo the testing procedure in a conventional healthcare facility. Finally, some donors may inaccurately answer to interview questions because blood donation is actually an excuse to miss work ${ }^{10}$. As for the laboratory screening of blood samples, the main limitation is the risk of false-negative results, which may still occur mainly during the initial stage of an infection, also known as the eclipse phase. Although this period has been significantly reduced with the use of molecular tests, it is still associated with a residual risk of TTI $^{11,12}$. In Brazil, some studies suggest that the residual risk of TTI is higher than the one seen in the US or Europe, highlighting the need for additional measures to further decrease this risk ${ }^{13}$.

Aiming at further reducing the risk of TTI, some blood banks have adopted the confidential unit exclusion (CUE) $)^{14}$. The blood donor is asked to confidentially answer if his/her blood is safe for donation in a separate query after the clinical interview. If the donor opts for the CUE, the unit is sent for laboratory testing of TTI, but it is not sent for donation ${ }^{6}$.

The CUE is used in many blood banks based on the fact that the interview and laboratory screening are not perfectly sensitive in capturing all $\mathrm{TTI}^{4}$. Furthermore, some specialists argue that this strategy helps preventing the spread of other emerging infectious agents that may be transmitted through a blood unit but are not routinely tested ${ }^{15}$. However, the CUE may also result in unnecessary waste of a high number of blood units in a scenario of scarce supplies, and the effectiveness of the CUE in correctly identifying units with TTI has been challenged in several studies ${ }^{15-21}$. The effectiveness of the CUE is also context-dependent. For example, among donors with low level of education, errors in the selection of the CUE option may be more frequent than in other groups, due to the misunderstanding of the instrument ${ }^{22}$. In this study, we investigated demographic characteristics and results of laboratory screening for TTI among blood donors who opted for the CUE, compared to blood donors who did not opt for the CUE in a blood bank in Sao Paulo, Brazil.

\section{MATERIALS AND METHODS}

In this cross-sectional study, we included consecutive blood donations that took place in the blood bank of Hospital Israelita Albert Einstein between February 2015 and December 2019. We included donations from sporadic donors, defined as those with up to one donation per year. For donors with more than one donation per year in the complete study period, regardless of the response for the CUE or the TTI screening tests results, only the first donation was considered for the study. Donations from replacement donors were excluded, assuming that replacement donations have different characteristics, such as a lower percentage of donors who are motivated by the access to screening test results, or a higher percentage of donors who will omit information on risk exposures driven by the desire to replenish blood supplies, although this evidence is still controversial ${ }^{23}$. We also excluded donations of platelets, leukocytes and bone marrow stem cells. Non-identifiable data including demographics, the CUE option, and laboratory TTI screening tests results were extracted from the institutional database. No additional tests were performed in stored samples and no additional information was collected from the donors included in the study.

The question on the CUE is performed immediately after the clinical interview and before the blood donation. The attendant (physician or nurse) explains that the CUE is confidential and asks if the donor feels comfortable that his/ her blood can be transfused into a recipient. The attendant shows a computer screen with two options: a green box saying "yes", and a red box saying "no". While the donor is selecting his/her answer, the blood bank attendant turns his face in the opposite direction of the screen.

The characteristics of study participants are presented using descriptive statistics. Comparisons between participants according to the CUE option were performed using chi square tests for categorical variables and $\mathrm{T}$ tests for numerical variables. We analyzed the association between the CUE option and TTI screening results using a chi square test and a multivariable logistic regression model to investigate if the CUE was associated with a positive result in the TTI screening, independently of covariates. For all analyses, we used the software Stata, version 15.1 (StataCorp., College Station, TX, USA). Two-tailed $\mathrm{p}<0.05$ were considered statistically significant for all the comparisons.

Serological tests for the screening of blood donors (anti-HIV, HBsAg, Anti-HBc, anti-HTLV-1/2, antisyphilis and anti-chagas disease) were performed using the ARCHITECT i2000SR immunoassay analyzer (ABBOTT 
Diagnostics, Chicago, USA). The real-time Polymerase Chain Reaction (PCR) tests to detect viral nucleic acids of $\mathrm{HIV} / \mathrm{HCV} / \mathrm{HBV}$ were performed using the $\mathrm{COBAS}^{\circledR}$ S201System, Roche NAT instruments (Roche, Basel, Switzerland). All tests were conducted according to the manufacturer's instructions.

This study was approved by the institutional Ethics Committee with exemption of the informed consent application (approval $\mathrm{N}^{\circ}$ 4.004.397).

\section{RESULTS}

Between February 2015 and December 2019, 32,261 blood donations were eligible for enrollment in the study. Of those, 32,179 did not opt for the CUE and 82 did (0.25\%). Demographics and TTI screening results are described in Table 1. Donors opting for the CUE were more likely males $(\mathrm{p}<0.001)$ and single $(\mathrm{p}=0.039)$; results from the laboratory tests revealed that this group had a higher prevalence of positive tests for HBV ( $\mathrm{p}=0.016)$ and syphilis $(\mathrm{p}=0.001)$. Among donors who did not opt for the CUE, 694 (2.2\%, 95\% CI 2.0-2.3) had a positive result among the TTI screening tests; among those who opted for the CUE, 5 $(6.1 \%, 95 \%$ CI 2.0-13.7) had a positive result among the TTI screening tests $(\mathrm{p}=0.033)$.

Table 2 presents results of the multivariable logistic regression addressing factors associated with a positive result in any of the TTI screening tests. The model included

Table 1 - Demographic characteristics of the study participants and results from the screening tests for transfusion-transmitted infections, according to the confidential unit exclusion (CUE) option.

\begin{tabular}{|c|c|c|c|}
\hline & $\begin{array}{c}\text { Donnors who did } \\
\text { not opt for the CUE } \\
N=32,179\end{array}$ & $\begin{array}{c}\text { Donnors who } \\
\text { opt for the CUE } \\
N=82\end{array}$ & $p$-value \\
\hline Male gender (\%) & $16,974(52.8)$ & $61(74.4)$ & $<0.001$ \\
\hline Mean age (standard deviation) & $35.4(11.7)$ & $33.3(10.8)$ & 0.097 \\
\hline $\begin{array}{l}\text { Ethnicity (\%) } \\
\text { White/caucasian } \\
\text { Black } \\
\text { Mixed } \\
\text { Asian } \\
\text { Native } \\
\text { Other/ missing }\end{array}$ & $\begin{array}{l}24,573(76.4) \\
1,091(3.4) \\
5,536(17.2) \\
883(2.7) \\
3(<0.1) \\
93(0.3)\end{array}$ & $\begin{array}{l}64(78.1) \\
2(2.4) \\
15(18.3) \\
1(1.2) \\
0(0) \\
0(0)\end{array}$ & 0.956 \\
\hline $\begin{array}{l}\text { Education (\%) } \\
\text { Elementary or incomplete middle school } \\
\text { Middle school } \\
\text { High school } \\
\text { Undergraduation (College) } \\
\text { Graduation } \\
\text { Missing }\end{array}$ & $\begin{array}{c}593(1.8) \\
1,728(5.4) \\
10,843(33.7) \\
15,826(49.2) \\
2,858(8.9) \\
331(1.0)\end{array}$ & $\begin{array}{c}1(1.2) \\
3(3.7) \\
34(41.5) \\
32(39.0) \\
9(11.0) \\
3(3.7)\end{array}$ & 0.102 \\
\hline $\begin{array}{l}\text { Marital status (\%) } \\
\text { Single } \\
\text { Married/common-law marriage } \\
\text { Divorced/widowed } \\
\text { Missing }\end{array}$ & $\begin{array}{l}14,475(45.0) \\
15,646(48.6) \\
2,004(6.2) \\
54(0.2)\end{array}$ & $\begin{array}{c}50(61.0) \\
29(35.4) \\
3(3.7) \\
0(0)\end{array}$ & 0.039 \\
\hline $\begin{array}{l}\text { HIV (\%) } \\
\text { Serology } \\
\text { PCR }\end{array}$ & $\begin{array}{l}65(0.2) \\
5(<0.1)\end{array}$ & $\begin{array}{l}0(0) \\
0(0)\end{array}$ & $\begin{array}{l}1.000 \\
1.000\end{array}$ \\
\hline $\begin{array}{l}\text { HBV (\%) } \\
\text { HBs Ag serology } \\
\text { PCR }\end{array}$ & $\begin{array}{c}378(1.2) \\
6(<0.1)\end{array}$ & $\begin{array}{c}4(4.9) \\
0(0)\end{array}$ & $\begin{array}{l}\mathbf{0 . 0 1 6} \\
1.000\end{array}$ \\
\hline $\begin{array}{l}\text { HCV (\%) } \\
\text { Serology } \\
\text { PCR }\end{array}$ & $\begin{array}{c}148(0.5) \\
4(<0.1)\end{array}$ & $\begin{array}{l}0(0) \\
0(0)\end{array}$ & $\begin{array}{l}1.000 \\
1.000\end{array}$ \\
\hline HTLV (\%) & $58(0.2)$ & $0(0)$ & 1.000 \\
\hline Syphilis (\%) & $270(0.8)$ & $5(6.1)$ & 0.001 \\
\hline Chagas disease (\%) & $52(0.2)$ & $1(1.2)$ & 0.126 \\
\hline $\begin{array}{l}\text { Any positive transfusion-transmitted infection } \\
\text { in the screening test (\%) }\end{array}$ & 694 (2.2) & $5(6.1)$ & 0.033 \\
\hline
\end{tabular}


Table 2 - Multivariable logistic regression addressing factors associated with a positive result in any screening test for transfusiontransmitted infections.

\begin{tabular}{lccc}
\hline & Odds Ratio & $95 \% \mathrm{Cl}$ & $\mathrm{p}$-value \\
\hline Age (per year increase) & 1.03 & $1.01-1.03$ & 0.000 \\
Male gender & 0.96 & $0.82-1.27$ & 0.668 \\
Marital status & & & - \\
$\quad$ Single & 1.00 (Referent) & - & 0.189 \\
$\quad$ Married/common-law marriage & 0.88 & $0.72-1.06$ & 0.928 \\
$\quad$ Divorced/widowed & 0.98 & $0.71-1.36$ & - \\
Education (\%) & & - & 0.507 \\
$\quad$ Elementary or incomplete middle school & 1.00 (Referent) & 0.127 \\
$\quad$ Middle school & 0.84 & $0.51-1.39$ & 0.002 \\
$\quad$ Unigh school & 0.72 & $0.47-1.09$ & 0.000 \\
$\quad$ Graduation & 0.51 & $0.34-0.77$ & $0.25-0.67$ \\
Option for the confidential unit exclusion (CUE) & 0.41 & $1.28-7.95$ & 0.013 \\
\hline
\end{tabular}

age, gender, marital status, education and the CUE option. The model showed statistically significant associations with older age $(\mathrm{OR}=1.03 ; 95 \%$ CI $1.02-1.03 ; \mathrm{p}<0.001)$, lower education level (linear trend $\mathrm{p}<0.001$ ), and with the CUE option (OR = 3.19, CI 95\% 1.28-7.95; $\mathrm{p}=0.013)$.

\section{DISCUSSION}

In this study including 32,261 blood donations collected in a single blood bank in Sao Paulo, Brazil, we showed that a very small proportion $(0.25 \%)$ of donors opted for the CUE. These donors were more often single males and were more likely than donors who did not opt for the CUE to have HBV, syphilis, and any positive results in the combined laboratory screening of TTI. This difference was statistically significant in both, the univariable and the multivariable analysis adjusted for age, gender, marital status and schooling (education level).

Our findings highlight that the CUE may be a useful tool to improve the safety for blood recipients, without unnecessary wasting of an exceeding number of blood units. In addition, our results suggest that some groups of donors, including single males, may benefit from educational strategies that highlight the importance of preventing TTI among blood recipients. Furthermore, these groups could benefit from interventions to distinguish donated blood unit testing from diagnostic testing in a patient with risk factors for a TTI.

The Ministry of Health of Brazil has implemented the CUE in $2004^{15}$, resulting in a high incidence of the CUE in the country; currently, $1.1 \%$ of all donations are discarded due to the CUE and $2.5 \%$ of all donations are discarded due to a prior CUE from the same donor. In contrast, $0.22 \%$ of the blood donations registered in the USA had used the
CUE strategy until 1992, when the CUE was withdrawn due to a low efficiency in reducing TTI $^{14}$. Similarly, a study conducted in Canada suggested that the CUE has a limited capacity to predict infections in the eclipse period (i.e., those that would not be revealed by the laboratory screening tests) and has rarely detected blood units from donors with exposures that had not been identified in the routine interview ${ }^{18}$. On the other hand, a study conducted in Iran showed that the CUE was associated with a higher prevalence of $\mathrm{HBV}, \mathrm{HCV}$ and $\mathrm{HIV}^{19}$. Interestingly, a study from Germany showed that the proportion of donors opting for the CUE was higher when nurses conducted the interview when compared to medical doctors, and when the CUE form was submitted anonymously instead of being delivered to a provider. This study has also shown that the format and colors used in the CUE form may influence the donor's understanding of the process ${ }^{15}$. These factors highlight that the CUE varies according to different cultural and epidemiological contexts. Our study included blood donors from a single institution, typically attended by patients with higher educational and socioeconomic status. This may in part explain why the proportion of donors opting for the CUE in our study is closer to data from the USA than to the national reference. While the sensitivity of the CUE was relatively low, detecting only 5 out of 699 donors with at least one positive result for TTI, the CUE was still significantly associated with TTI in both the univariable and the multivariable analysis.

Our study has a few limitations. We were restricted to a single blood bank, which represented a limited blood donor population, so our results should be interpreted with caution in different contexts. Our study used serological screening tests and did not include additional confirmation exams. In addition, we analyzed the association between CUE 
and TTI screening tests, but we were unable to address if donors opting for the CUE were more likely to be in the window period for TTI; similarly, because we opted for using a cross-sectional design, we were also unable to obtain follow-up samples from donors who opted for the CUE to investigate if the CUE is associated with subsequent seroconversion to TTI.

Although the CUE remains a controversial procedure in the blood donation setting, it is also debatable if the central question in the currently used version of the CUE ("is your blood safe for donation?") should be replaced by a less subjective, non-judgmental question. For instance, a question focused on the eclipse phase for HIV laboratory detection ("have you had unprotected sex in the past two weeks?") or a question tackling a potential need for diagnostic tests as the main reason for donation ("do you want your sample to be tested but not donated?") might be suitable to improve the CUE procedure and further increase the safety for recipients.

Since the publication of the update of technical standards for the hemotherapy activity by the Ministry of Health of Brazil in 2016, the CUE became a non-mandatory recommendation ${ }^{24}$. After the implementation of this guideline, some points are still controversial: what to do with the donor who excludes himself in some donations and not in others; what to do with the components coming from non-self-excluded seronegative donations by those aforementioned donors; what is the amount and impact of the donor's lack of understanding about the CUE process in our country; what is the risk of stigmatizing the selfexcluded donor due to the lack of understanding about the CUE process, among others. Replacement donors may understand the blood donation process better than sporadic donors, since they regularly donate blood, are familiar with the blood bank workflow and may be acquainted with the importance of blood safety. Brazil is a continental country, with significant regional heterogeneities. Larger studies in different regions of the country, as well as the analysis of data at national level will be fundamental for establishing the effectiveness of the CUE in our setting. These analyses are essential to maintain the greatest possible safety in the transfusion procedures, avoiding unnecessary disposal of blood components and rationalizing the costs of the national blood therapy activities.

In conclusion, the CUE effectiveness depends on the context so that evaluations should be carried out locally in order to explore the balance between unnecessarily wasted blood units and improvements in donor screening. It remains unknown whether the CUE effectively helps preventing the TTI that are not detected by laboratory tests. Improvements in the CUE process could be explored as an additional strategy to ensure the safety of recipients in the blood donation setting.

\section{ACKNOWLEDGMENTS}

We thank the blood donors who voluntarily provided invaluable blood products for patients in need.

\section{AUTHORS' CONTRIBUTIONS}

MVVD, KMB and VIAS designed the research study; LD and CB contributed with data collection; VIAS, MVVD and KMB analyzed the data; MVD, KMB and VIAS wrote the manuscript. All authors reviewed and approved the final draft.

\section{REFERENCES}

1. American Red Cross. Importance of the blood supply. [cited 2021 Jun 28] Available from: https://www.redcrossblood. org/donate-blood/how-to-donate/how-blood-donations-help/ blood-needs-blood-supply.html

2. European Commission. Directorate General for Health and Food Safety. Summary of the 2018 annual reporting of serious adverse reactions and events for blood components. [cited 2021 Jun 28] Available from: https://ec.europa.eu/health/sites/ default/files/blood_tissues_organs/docs/2018_sare_blood_ summary_en.pdf

3. Brasil. Ministério da Saúde. Secretaria de Atenção à Saúde. Departamento de Atenção Especializada e Temática. Caderno de informação: sangue e hemoderivados: dados de 2016. Brasília: Ministério da Saúde; 2018. [cited 2021 Jun 28] Available from: https://bvsms.saude.gov.br/bvs/publicacoes/ caderno_informacao_sangue_hemoderivados_2016.pdf

4. Brasil. Ministério da Saúde. Gabinete do Ministro. Portaria $\mathrm{n}^{\circ} 1.376$, de 19 de novembro de 1993. Aprova alterações na Portaria $n^{\circ} 721 / \mathrm{GM}$, de 09.08 .89 , que aprova normas técnicas para coleta, processamento e transfusão de sangue, componentes e derivados, e dá outras providências. Diário Oficial da União, Brasília, 2 Dez. 1993. [cited 2021 Jun 28] Available from: http://redsang.ial.sp.gov.br/site/docs_leis/ps/ ps29.pdf

5. Pinho AM, Lopes MI, Lima MJ, Castro V, Marteleto MA. Triagem clínica de doadores de sangue. Brasília: Ministério da Saúde; 2001. [cited 2021 Jun 28] Available from: http://bvsms.saude. gov.br/bvs/publicacoes/cd07_20.pdf

6. Flausino GF, Nunes FF, Cioffi JG, Carneiro-Proietti AB. O ciclo de produção do sangue e a transfusão: o que o médico deve saber. Rev Med Minas Gerais. 2015; 25:258-67.

7. Brasil. Agência Nacional de Vigilância Sanitária. Diretoria Colegiada. Resolução - RDC nº 34, de 11 de junho de 2014. 
Dispõe sobre as boas práticas no ciclo do sangue. Diário Oficial da União, Brasília, 11 jun. 2014. [cited 2021 Jun 28] Available from: https://inc.saude.gov.br/download/resolucao-rdc-n-34de-11-de-junho-de-2014.pdf

8. O'Brien SF, Xi G, Yi QL, Goldman M. Understanding nondisclosure of deferrable risk: a study of blood donors with a history of intravenous drug use. Transfus Med. 2010;20:15-21.

9. O’Brien SF, Ram SS, Yi QL, Goldman M. Donor's understanding of the definition of sex as applied to predonation screening questions. Vox Sang. 2008;94:329-33.

10. Petersen LR, Doll LS. Human immunodeficiency virus type 1-infected blood donors: epidemiologic, laboratory, and donation characteristics: the HIV Blood Donor Study Group. Transfusion. 1991;31:698-703.

11. McFarland W, Mvere D, Shamu R, Katzenstein D. Risk factors for HIV seropositivity among first-time blood donors in Zimbabwe. Transfusion. 1998;38:279-84.

12. Jullien AM, Courouce AM, Richard D, Favre M, Lefrere JJ, Habibi B. Transmission of HIV by blood from seronegative donors. Lancet. 1988;2:1248-9.

13. Sabino EC, Gonçalez TT, Carneiro-Proietti AB, Sarr M, Ferreira JE, Sampaio DA, et al. Human immunodeficiency virus prevalence, incidence, and residual risk of transmission by transfusions at Retrovirus Epidemiology Donor Study-II blood centers in Brazil. Transfusion. 2012;52:870-9.

14. Brasil. Ministério da Saúde. Agência Nacional de Vigilância Sanitária. Diretoria Colegiada. Resolução - RDC No 153 , de 14 de junho de 2004. Determina o regulamento técnico para os procedimentos hemoterápicos, incluindo a coleta, o processamento, a testagem, o armazenamento, o transporte, o controle de qualidade e o uso humano de sangue, e seus componentes, obtidos do sangue venoso, do cordão umbilical, da placenta e da medula óssea. Diário Oficial da União, Brasília, 14 jun. 2004. [cited 2021 Jun 28] Available from: http://www.aids.gov.br/pt-br/legislacao/resolucao-da-anvisandeg-1532004
15. Sümnig A, Konerding U, Kohlmann T, Greinacher A. Factors influencing confidential unit exclusions in blood donors. Vox Sang. 2010;98:e231-40.

16. Almeida-Neto C, Liu J, Wright DJ, Mendrone-Junior A, Takecian PL, Sun Y, et al. Demographic characteristics and prevalence of serologic markers among blood donors who use confidential unit exclusion (CUE) in São Paulo, Brazil: implications for modification of CUE polices in Brazil. Transfusion. 2011;51:191-7.

17. Gonçalez TT, Sabino EC, Kaidarova Z, Carneiro-Proietti AB, Miranda C, Loureiro P, et al. Does deferral for high-risk behaviors improve the safety of the blood supply? Transfusion. 2019;59:2334-43.

18. O’Brien SF, Fan W, Xi G, Yi QL, Goldman M. Evaluation of the confidential unit exclusion form: the Canadian Blood Services experience. Vox Sang. 2010;98:138-44.

19. Rad F, Sajjadi SM, Hassanzadeh R, Maghsudlu M. Confidential unit exclusion (CUE): double edged sword for blood transfusion center: a ten-year study on volunteer blood donors in Kohgiluyeh and Boyer Ahmad province, Iran. Transfus Clin Biol. 2019;26:253-6.

20. de Kort W, Prinsze F, Nuboer G, Twisk J, Merz EM. Deferral rate variability in blood donor eligibility assessment. Transfusion. 2019;59:242-9.

21. Sauvage C, Spinardi R, Pelat C, Pouget T, Danic B, Woimant $\mathrm{G}$, et al. Noncompliance with blood donor selection criteria Complidon 2017, France. Transfusion. 2020;60:73-83.

22. Eder A. Effectiveness of confidential unit exclusion for screening blood donors. Rev Bras Hematol Hemoter. 2011;33:330-1.

23. Allain JP. Moving on from voluntary non-remunerated donors: who is the best blood donor? Br J Haematol. 2011;154:763-9.

24. Brasil. Ministério da Saúde. Gabinete do Ministro. Portaria $\mathrm{n}^{\circ} 158$, de 4 de fevereiro de 2016. Redefine o regulamento técnico de procedimentos hemoterápicos. Diário Oficial da União, Brasília, 4 fev. 2016. [cited 2021 Jun 28] Available from: https://bvsms.saude.gov.br/bvs/saudelegis/gm/2016/ prt0158_04_02_2016.html 